\title{
Personhood and partialism in African philosophy
}

\section{Motsamai Molefe}

To cite this article: Motsamai Molefe (2018): Personhood and partialism in African philosophy, African Studies

To link to this article: https://doi.org/10.1080/00020184.2018.1519337

曲 Published online: 27 Sep 2018.

Submit your article to this journal

View Crossmark data $₫$ 


\section{Personhood and partialism in African philosophy}

\section{Motsamai Molefe}

University of the Witwatersrand

\begin{abstract}
This article ascertains what philosophical implications can be drawn from the moral idea of personhood dominant in African philosophy. The article aims to go beyond the oft-made submission that this moral idea of personhood is definitive of African moral thought. It does so by advancing discourse with regard to personhood by exploring its relationship with another under-explored idea in African ethics, the idea of partialism. The article ultimately argues that the idea of personhood can be associated with two (related) sorts of partialisms: agent-related and other-centred partialisms.
\end{abstract}

\section{ARTICLE HISTORY}

Received 29 January 2017

Accepted 13 March 2017

\section{KEYWORDS}

agent-neutral reasons; agent-relative reasons; African ethics; partialism; personhood

In this article, I philosophically analyse the notion of personhood in African philosophy to ascertain what contributions it can make to African ethics. I am aware of at least three distinct concepts of personhood in the literature on African philosophy. Firstly, personhood is used to capture two sorts of metaphysical commitments in the tradition. On the one hand, it is offered as an account of personal identity, particularly whether it is constituted partially/entirely by communal relations (Louw 2004; Mbiti 1969; Molefe 2017a). On the other hand, it is used to give philosophical anthropological accounts, i.e. accounts about human nature whether it is constituted by physical and/or spiritual properties (see Kaphagawani 2004). Secondly, the idea of personhood features quite significantly in discussions of political theorisations about rights. Moderate communitarians offer an account of personhood reminiscent of the western naturalist tradition of rights, wherein some understanding of a 'person' is offered as a basis for human rights (Donnelly 1982; Gyekye 1992, 1997). Restricted communitarians appear to offer an account of personhood that relegates rights to a secondary status (Menkiti 1984; Nkondo 2007). Finally, the idea of personhood is used to express a particular kind of moral commitment. Specifically, it is used to refer to those moral agents who lead morally virtuous lives (Menkiti 1984; Wiredu 1992). This article focuses on this last idea of personhood.

My aim in this article is to demonstrate that this moral idea of personhood can be associated with two kinds of partialisms, namely: agent-centred and other-centred partialisms. 'Partialism', in a moral context, is the doctrine that one is justified to show favouritism to her special relationships. 'Agent-centred partialism' refers to the favouritism one accords to herself as a moral agent (Cottingham 1991). 'Other-centred partialism' refers to the favouritism one displays to her close relations like family and friends, among others (Cottingham 1983). 
I engage in this project for two major reasons. Firstly, African scholars have noted the importance of the moral idea of personhood in African moral thought. For example, in the literature one will find expressions like this notion is 'germane', 'more dominant' and 'definitive' of African moral thought (Ikuenobe 2006: 117; Masolo 2010: 135; Wiredu 2009:13). One of the most influential African philosophers, Kwasi Wiredu makes the following observation: 'The philosophical implications of the normative conception of a person are legion, and we will not pursue them here' (2009:16). One gets a sense from reading African scholars talk of this notion that it has a lot to offer philosophically. But, African scholars are yet to demonstrate contributions this moral idea of personhood can make to advance moral discourse in philosophy. In this article, I elucidate on one of the legion implications that can be associated with personhood, specifically that it can be associated with two sorts of partialisms.

Secondly, a close analysis of the literature in African philosophy reveals that little philosophical attention has been devoted to the topics of partiality and/or impartiality (Molefe 2016a). The debate in moral philosophy is whether morality by its very nature is best construed in terms of either partiality or impartiality (Rachels \& Rachels 2015). This debate has not taken ground in African philosophy (Molefe 2016a). The little one finds in the literature is not philosophically inquisitive. For example, Wiredu defends a moral principle of sympathetic impartiality, but treats the idea of impartiality as if it is philosophically incontrovertible (Wiredu 1992). He does not define or even defend why this idea is central in his interpretation of African ethics. The same can be said about Kwame Gyekye's unjustified commitment to impartiality as a defining feature of morality (Gyekye 2004). On the other hand, one finds scholars who take the stance that partiality is a defining feature of African moral thought (Appiah 1998; Metz 2012a). These, however, do not give philosophical justification for their commitment to partiality. ${ }^{1}$

Recently, I have complained about this state of affairs in the literature on African philosophy with regard to partiality (Molefe 2016a). In another place, I defended the position that African ethics is best construed in terms of partiality rather than impartiality ${ }^{2}$ (Molefe 2016a, 2016b). Elsewhere, I problematised Wiredu's commitment to impartiality as a defining feature of morality (Molefe 2016c). In another place, I have suggested how partiality and impartiality can hang together in moral philosophy (Molefe 2017b). To take issues forward with regard to partiality in African moral theorisation; in this article, I show how the two partialisms are connected with the idea of personhood.

Some scholars in the African tradition have come close to realising that there might be a relationship between personhood and partiality; but, they have never made it their sole project to focus on this relationship or even attempt to spell it out (Metz 2012a; Van Niekerk 2007). And, to the best of my knowledge, none in the literature goes to the extent of specifying the two distinct sorts of partialisms the way l intend to do in this article. ${ }^{3}$

This article is dedicated to spelling out this under-explored relationship between personhood and partiality. In spelling out this relationship, I do not defend these two moral notions in and of themselves. I simply limit myself to studying the relationship that holds between them, with the purpose of unpacking the moral implications of the idea of personhood with regard to partiality. I hope this analysis will contribute to the scant literature on partiality in African philosophy.

I structure this article as follows. In the first section, I introduce the distinction between the agent-centred and other-centred partialisms in light of the debate between partiality 
and impartiality in moral philosophy. The aim here is to contextualise the discussion in moral philosophy and to introduce the relevant partialisms. I then discuss the idea of personhood. Here, I show how the notion of personhood is usually interpreted as a dialogical moral theory, which integrates the individualistic and communitarian facets of African ethical thought. I conclude by showing that the individualistic feature of personhood accommodates the agent-centred partiality and the communitarian facet the othercentred partiality.

\section{Contextualising partialism}

The defence of partialism, particularly in the western moral tradition, emerged as a response to the dominant deontological and consequentialist accounts. These influential moral approaches posited impartiality as a defining feature of morality (Wolf 1992). By 'impartiality', these theories do not mean, at least on the face of it, something that is entirely unintuitive. Impartiality is the idea that the interests of all should count and that they should count equally (Singer 1979). Should a moral theory continuance partiality then it cannot be properly called 'moral' since it is characterised by favouritism, which is predicated on arbitrary discrimination among human interests. Such an understanding of impartiality is captured succinctly thus: ' ... morality requires the impartial consideration of each individual's interests' (Rachels \& Rachels 2015: 10). James and Stuart Rachels' understanding of morality comprises two elements, namely: (1) morality as a rational enterprise; and (2), morality as defined in terms of impartiality (2015: 10).

I will reserve my comments with regard to rationality since they are not relevant in this project. It occurs that Rachels and Rachels are arguing that impartiality is a defining feature of morality since there is no rational basis to discriminate among persons given that they are all equally human; and, as such, the way we treat them should manifest equal consideration for their interests and welfare (Wolf 1992: 243). Another interesting way to make sense of impartiality, according to Peter Singer, an influential proponent of this view, is in terms of what he calls the 'Impartialist thesis' (1979: 11).

He defines this thesis to amount to the idea that 'ethics requires us to go beyond the "I" and "you" to the universal law, the universalizable judgement, the standpoint of the impartial spectator or ideal observe' (Singer 1979: 11). Central to this understanding of morality is the crucial distinction between the natural/personal point of view and the moral point view (Wolf 1999: 204-6). A moral agent is expected to abstract from a natural point of view to occupy a special moral position. The defining feature of this moral stance to characterise a moral agent is that she must assume an impersonal posture or what may be considered 'God's' perspective, wherein the interests of all are taken as equal (Musschenga 2005: 2).

This kind of approach to ethics is reminiscent of William Godwin's (1973) oft-cited example of the Bishop of Canterbury and the chambermaid. Godwin insists that if the two are caught up in a burning house, and we can only save one; ours is to impartially consider whose saving will maximise welfare. Facts about our personal relationships with them and how much we care about these relationships may be interesting, but are morally irrelevant in light of the moral situation before us - welfare maximisation is the only consideration in the moral sphere. Famously, Godwin goes on to ask a rhetorical question about what magic is there in the fact that one is my mother or wife or even daughter (Godwin 1973: 41-2). What comes out poignantly from this kind of 
understanding morality is that a self, her projects and special relations are considered to be irrelevant in the moral domain. Morality requires us to be neutral, impersonal and impartial (Jollimore 2014).

Another way to express the idea of impartiality as represented here is in terms of agentneutral reasons for acting. 'Agent-neutral reasons' are those that 'holds that each of us has reason to promote everyone's good. Another way of making this point ... is that consequentialism gives us the common aim of promoting the general or impersonal good' (MacNaughton \& Rawling 2006: 427). In our distribution of moral goods, whatever these may be, we should do so motivated by considerations that are devoid of any personal reference or attachments; instead, our motivation must be the promotion of the good of anyone and even everyone, so far as is possible. As such, morality by its very nature is essentially characterised by agent-neutral reasons.

Partialism emerges as a response to this kind of impartialist understanding, which construes morality as essentially characterised by agent-neutral reasons. The underlying moral intuition informing partiality is that special relationships with our own projects, friends, families and colleagues are an essential part of our identity as distinct individuals with varied goals and interests (Cottingham 1986). If considerations of our special relationships are considered to be outside of the purview of morality then morality is accused of closing out crucial facets of a robust human life. Moreover, if morality by definition requires that we distance ourselves from our special relationships then it is not only the case that it is too demanding; but it also seems to be demanding the psychologically impossible (Williams 1974: 198). This objection generally goes by the name of 'alienation': the idea that impartiality is asking individuals to sacrifice not only the people and things they value; but more, it requires us to sacrifice who we are in the altar of being 'moral' (Williams 1974: 198). The force of this objection is that even if it were psychologically possible to do so, it seems to be morally defective to do so.

The defect according to John Cottingham of impartiality lies in that it overlooks the fact that a 'self' is at the heart of the project of morality. If morality truly, as Socrates claimed, is about how ought I to live, then a self as a moral agent must be at the heart of the project of morality. This idea is captured thus by Cottingham: 'For to be a person, to have a sense of identity and personal integrity, implies the possession of plans, projects and desires which have a special status in your scale of values precisely because they are yours' (1983: 88). These 'plans, projects and desires' belong to an agent and they encapsulate what makes her distinct and special as a human being. And, if her projects are to succeed and they truly mean anything to her, she ought to treat them as weightier than those that are not her own. Cottingham refers to this kind of prioritisation of one's plans, projects and desires as 'agent-related partiality' (1986: 364). This kind of approach to ethics then, unlike impartiality, is grounded on agent-relative reasons. A commitment to agent-relative reasons is a declaration of the fact that there are things that reflect one's self-interest, desires and plans without which one cannot speak meaningfully of a self.

There is another kind of partiality associated with the agent-related partiality: the otherrelated partiality. If partiality is defined in terms of favouring one's own then 'one's own' can be construed in two (related) ways (Cottingham 1983). On the one hand, partiality can be understood in terms of self-favouritism as captured by the idea of agent-related partiality; and, it can also be captured in terms of other-centred partiality, wherein we 
manifest favouritism to our special relationships like family and friends, among others (Cottingham 1983, 1986, 1991).

I say these two kinds of partialisms are related because my special relationship with others like family, friends and colleagues are usually part of my own projects. Agentcentred partiality flags the importance of my plans, projects and desires for capturing my own identity, integrity and purpose (for my own existence) on this planet (Cottingham 1986; Williams 1981). Other-centred partiality as represented by friendship and love relationships are considered 'to unquestionably rank among the greatest goods in life' because they add a distinctive layer of meaning to our lives (Wolf 1992: 243). These relationships of love, by their very nature are not universalising instead they operate on an exclusionary logic, i.e. they thrive precisely because they are built on the fact that they exclude others and the exclusion is generally considered to be morally acceptable (Appiah 1998; Cottingham 1986). For example, the objectionable nature of adultery is predicated on the fact that it violates this exclusionary logic. The meaning we derive from our special relationships like love requires this kind of exclusionary logic, which creates inner and outer circles of discrimination that impartiality jettisons as immoral (Ramose 2003; Wolf 1992).

Above, I have just sketched impartiality as a context for the emergence of partiality in moral philosophy. I have also given a rough, I hope theoretically useful, distinction between an agent-centred and other-centred partialisms. In the following sections, I elaborate on the normative idea of personhood, and then I unpack its individualistic and communitarian facets, respectively.

\section{The moral notion of personhood}

Ifeanyi Menkiti, a Nigerian philosopher, is credited with being the first African philosopher to adumbrate on the moral notion of personhood in African philosophy (Wiredu 1992, 2009). In fact, Wiredu comments approvingly on Menkiti's analysis of this African normative concept of personhood as follows:

In contemporary African philosophy, as far as I know, the first exposition of this normative conception of a person was given by Menkiti in an article of super-lative beauty entitled 'Person and Community in African Traditional Thought'. (2009:16)

In two separate articles, Menkiti $(1984,2004)$ articulated his understanding of an African conception of personhood. The title of Menkiti's first article is not specific that he is after a normative concept of personhood - the title is mentioned in the quotation above from Wiredu. In this article, Menkiti (1984: 171) simply states that his aim is to articulate $a$ certain African conception of personhood without specifying which between the metaphysical and/or the normative is under consideration. ${ }^{4}$ The 2004 article's title is very explicit with regard to which notion of a person is central to this analysis: 'On the normative conception of a person'. 5

To elaborate on this normative notion of personhood, I will rely mainly on Menkiti's elucidations of it. Menkiti notes 'personhood is something which has to be achieved, and is not given simply because one is born of human seed' (1984: 172). Here, Menkiti appears to be drawing the distinction between merely being human, a biological fact, and being a person, a moral consideration. We simply have to be born of a human seed to be human and we need do nothing else. But, to be a person, one needs to go beyond 
what is biologically given to add moral dimensions to her humanity. Menkiti talks in this fashion about adding moral dimensions to our biological life:

We must also conceive of this organism as going through a long process of social and ritual transformation until it attains the full complement of excellencies seen as truly definitive of man. (1984: 172)

The idea of a man is used normatively to signify human moral achievements. In other words, according to Menkiti, to be a person amounts to equipping our humanity with 'the full complement of excellencies'. In another place, Menkiti talks about how the internalising of moral norms of a society will convert 'what was initially biologically given' to have 'inbuilt excellencies' (1984: 173). What is beginning to emerge here is that Menkiti associates the idea of personhood with a development of a sound character, wherein one's life is characterised by moral virtue (Behrens 2013; Gyekye 2010).

Two central ideas may be gleaned from this rough analysis of Menkiti's analysis. To talk of a normative idea of a person is to make claims about an agent's moral achievements. The idea of achievements as represented by Menkiti calls to mind a collection of certain moral habits or virtues that commends an agent's life as worthy of moral praise (Metz 2010; Wiredu 2009). Thus, to be called a person is to be pronounced as one leading a morally triumphant life; and to be called a non-person is to be denied this status of moral achievement, without decrying one's humanity biologically speaking.

Two further ideas can be harvested from Menkiti's analysis of personhood. Firstly, Menkiti's analysis can be read as implying a self-realisation approach to ethics (Metz 2007). Secondly, Menkiti's talk of personhood qua self-realisation approach to ethics can be enriched if we can draw a distinction between the state of personhood to be achieved (end) and how that state of personhood is achieved (means).

One of the influential scholars of African ethics, Metz, notes that talk of personhood as best interpreted as a self-realisation approach to ethics dominates how African scholars usually interpret African ethics (Metz 2007: 331; see also Bujo 1998, 2001; Magesa 1997; Shutte 2001). For example, Justice Yvone Mokgoro notes that African ethics requires moral agents 'to achieve self-fulfilment through a set of collective social ideals' (1998: 2). Another expert of African ethics, Mogobe Ramose, also avers that a moral agent 'is enjoined, yes, commanded as it were, to actually become a human being' (1999: 52). Augustine Shutte, an influential scholar of Ubuntu, notes:

The moral life is seen as a process of personal growth ... Our deepest moral obligation is to become more fully human. And this means entering more and more deeply into community with others. So although the goal is personal fulfilment, selfishness is excluded. (2001: 14)

It becomes clear in light of the above commentators that African ethics is dominated by interpretations of it as a self-realisation account, wherein a moral agent is expected to realise their ideal or true humanity. This realisation of a moral status of a true humanity will mark her out as a person. The sole or chief goal of morality, in this rendition of African ethics, is the perfection of one's humanity by developing certain moral dispositions or virtues befitting a true human life.

Individuals who have attained such a moral status are called persons and they are usually characterised as manifesting particular moral virtues. For example, Desmond Tutu, another commentator on Ubuntu, notes: ${ }^{6}$ 
When we want to give high praise to someone we say, 'Yu, u nobuntu'; 'Hey, so-and-so has ubuntu.' Then you are generous, you are hospitable, you are friendly and caring and compassionate. You share what you have. It is to say, 'My humanity is caught up, is inextricably bound up in yours'. (1999: 31)

It is crucial to note that Tutu represents a person, in a moral sense, as one characterised by certain relational virtues. In other words, she is characterised by virtues that emphasise connectedness and connections to others: a person is kind, generous, hospitable, friendly, and so on. In other words, the idea of a person imagines a relational morality, i.e. one can never be moral outside of (positive) relationships with others. Relationships are a necessary context for a possibility of one achieving personhood. Mokgoro, also commenting on African ethics, notes that it emphasises these key values: 'Group solidarity, conformity, compassion, respect, human dignity, humanistic orientation and collective unity' (1998: 3). So, there is no doubt that African ethics imagines a relational ethics. So far, we have noted that the idea of personhood is typically construed as a self-realisation moral account; and, as I have just noted, that this ethical framework takes a relational orientation. The reader may sense a tension between self-realisation orientation and the relational facets of this idea of a person.

This potential tension can be clarified by appeal to the distinction between means and ends, as suggested above (Tshivhase 2013). The idea of personhood can be read as entailing a self-realisation account. But, this facet of self-realisation should be understood as focusing mainly on the ends or what the theory posits as the goal of morality itself. The goal of morality within a self-realisation framework is for a human being to become moral and lead a truly human life. Read in this light, a self-realisation account by its very nature is individualistic.

To say a self-realisation account is 'individualistic' is to assert that it locates the ultimate good in some property intrinsic to an individual (Behrens 2011). Put differently, what is to be perfected is a feature(s) of a human being. As such, theories that ground the good in some internal feature like welfarism and egoism are individualistic (Metz 2012b). The idea of personhood insofar as it requires a moral agent to perfect her own humanity is individualistic.

The relational facet emerges in light of the means one is to employ to achieve personhood. We noted above Mokgoro asserting that one is to achieve self-fulfilment through a set of social ideals. Typically, African scholars converge on the idea that personhood can only be achieved in some kind of social relationship. For example, the idea of Ubuntu is usually captured by appeal to the maxim that 'a person is a person through other persons'. In other words, one can only achieve moral perfection, personhood, 'through other persons'. The phrase, 'through other persons', flags certain social relationships or certain ways of relating with others as the only effective means for character formation and perfection (Metz 2012a; Shutte 2001). John Mbiti's (1969) maxim, 'I am because we are', interpreted morally, also implies that it is in the presence of others, by their assistance and by collaborating with them that moral perfection is possible. It is for this reason that Menkiti notes the following about African ethics in light of Mbiti's assertion - I am because we are: 'And to ... (that) extent ... morality demands a point of view best described as one of beingness-with-others' (2004: 324).

So, what emerges is that one can only achieve personhood by being in a community or some kind of relationship with others. Several implications may be read off this idea of 
achieving personhood through some kind of relationship. But one that stands out for me is the idea that part of what is required in these relationships is positively relating to others to promote their well-being (Metz 2010: 83; Wiredu 1992: 200). Being with others in relationships inter alia requires that we respond positively to their needs and well-being (Gyekye 2004). Put simply, an essential part of being caught up in relationships with others requires that we exercise our other-regarding duties towards them (Gyekye 2004; Lutz 2009). In other words, I can only perfect my humanity by relating positively with others, an activity that requires that I exercise my duties of promoting their well-being.

What is emerging from this analysis of means and ends with regard to personhood is that it entails a dialogical morality insofar as it marries the individualistic and communitarian features. With regard to the fact that the sole goal of morality is the perfection of one's own humanity it follows that morality is individualistic; and, to the effect that moral perfection can only be achieved by relating positively with others, it follows that the means required are communitarian by nature. In other words, the best way to realise one's humanity is by reaching out to empower and benefit other human beings. The dialogical nature of this moral gem contained by this idea of personhood is expressed thus by David Lutz:

In a true community, the individual does not pursue the common good instead of his or her own good, but rather pursues his or her own good through pursuing the common good. The ethics of a true community does not ask persons to sacrifice their own good in order to promote the good of others, but instead invites them to recognize that they can attain their own true good only by promoting the good of others. (2009:314)

Roughly, the idea of the common good is usually captured by appeal to an art motif of a Siamese crocodile with two heads and one stomach (Gyekye 2004; Wiredu 1992). This allegory is usually interpreted to represent the well-being of all human beings - the common stomach. The 'common good' is the idea that there are a set of basic conditions and needs are necessary for a satisfactory human life (Gyekye 2004). Sometimes, the common good is referred to as the 'human good' (Gyekye 2004: 47). The common good represents a basket of goods necessary for a human life as such to be ordinary or even flourishing. The individuals' goal of self-perfection must be understood within a framework wherein she has duties to contribute to the good of all. The very moral act of promoting the good of others simultaneously promotes my own good. As such, the individual and communitarian facets are knit together in this idea of personhood.

In the next section, I show how the individualistic facet is connected to agent-related partiality and the communitarian facet can accommodate the other-centred partiality.

\section{Personhood, individualism and agent-centred partialism}

Above I showed how the idea of personhood is dominantly construed within a self-realisation moral framework, wherein the sole goal of morality is the perfection one's own humanity. Insofar as the idea of personhood posits one's own humanity as the ultimate object of morality, we observed that this renders this account of ethics individualistic. To unfold the nature of the reasons that are central to a self-realisation moral approach I invoke Metz's criticism of this approach in his search for the most plausible African moral theory. Metz's criticism reveals the nature of the reasons (for acting) that informs a self-realisation approach. He notes: 
I now question the theory's ability to provide an attractive explanation of them. If I ask why I should help others, for example, this theory says that the basic justificatory reason to do so ... is that it will help me by making me more of a mensch or a better person. (Metz 2007: 330)

In this particular context, Metz is offering a criticism of a self-realisation moral theory, but I think his criticism carries my point with regard to the nature of reasons characterising a self-realisation account. The only and best explanation or what Metz refers to as 'the basic justificatory reason' that inform a self-realisation account ultimately invokes the agent and the benefit that accrues to her as the essential reason for acting. In other words, the reasons that ground an agent's actions are agent-relative. The reasons for why I act the way I do in the project of perfecting myself ultimately are about me and my goal of perfecting myself. To say these reasons are about me and my personal goals of moral development does not make these reasons selfish, it simply identifies their source. In other words, my reasons for seeking to attain a status of personhood are not merely general but they are essentially personal, i.e. I realise it is good for me as a human being to achieve this status of personhood.

Another way to reveal the self-favouritism or agent-relative reasons characteristic of the moral idea of a person is to construe them in terms of the idea of projects as articulated by Williams (1981) and Cottingham (1991), among others. ${ }^{8}$ The idea of projects is crucial insofar as it emerges as an answer to moral-existential questions about one's purpose and goal for being on this planet (Williams 1981). And, if my goal, as the idea of personhood indicates is living a truly human life, a goal that requires that I perfect my own humanity then this can be understood as a defining project of my existence as a human being. And, if my moral project for being here on earth is to grow morally and ultimately morally triumph then surely l ought to accord priority to this project. It is in this sense that the idea of personhood can be understood in terms of an agent-related partiality. As an agent, I have stronger and agent-relative reasons to achieve the goal of a true human life.

\section{Personhood, communitarianism and partiality}

Crucial to recall is that the moral project of turning that which was biologically given to be a bearer of a true or ideal humanity requires an agent to relate positively with others, by way of promoting their well-being. One, here, may offhandedly assume that this kind of promotion of the common good is indiscriminate and is grounded on agent-neutral reasons. African scholars converge on the idea that wherever possible we ought to promote the good of all but they always depart from a stance that operates within the ambit of other-centred partiality. In other words, though we have a duty to promote the common good, our marching orders must proceed from the inner circle of special relationships to the outer circle of strangers. This insight is communicated by several African scholars (Appiah 1998; Bell \& Metz 2011; Ramose 2003). Associated with the idea of African ethics is the high prize usually accorded to family and kinship, and these are usually granted priority (Behrens 2011; Shutte 2001).

For example, Anthony Appiah comments thus on African ethics:

A second significant aspect of traditional ethical thought relates to the extended family or clan. This form of moral thought permits someone, the agent, to treat someone else, the patient, in a certain manner because the two are related ... I might give shelter to someone 'because she is my kinswoman'. (1998: n.p.) 
Here, Appiah notes that reasons for acting appear to have a format of being 'anti-universalizing' or they take a shape of being 'indexical' (1998: n.p.). Though African ethics is geared towards the promotion of the good of all, that duty is understood to be best exercised by favouring one's own within her extended family. To talk of these reasons for acting as being 'indexical' is the same thing as saying they are agent-relative - because she is my kinswoman.

Another influential African scholar of Ubuntu, Ramose, appears to support the kind of moral logic that is characterised by prioritising one's close relations. Ramose commenting on how Ubuntu functions notes:

According to this understanding of the family, it is unethical to withhold or to deny botho/ ubuntu towards a member of the family, in the first place, and the community at large. In other words, charity begins at home. (2003: 386)

Here, Ramose makes it clear that African ethics operate on the basis of prioritising one's family before she extends her hand to the community at large. The idea that charity begins at home is fundamental to African moral thought. One who embarks on a Mother Teresa's helping-the-world-spree and yet neglects her own family would be seen a moral leper, far from being a person. Wiredu also supports this kind of partialism in African ethics, or so I interpret him. What is interesting, however, about Wiredu's comments on other-centred partiality is that it is located in a context where he is considering the implications of taking the idea of personhood seriously.

Wiredu asks himself the question: 'What, then, in its social bearings, is the Akan ideal of personhood?' (1992: 200). I understand the phrase, 'in its social bearings', to be seeking to unravel the implications of this normative idea of personhood. In what follows, Wiredu elucidates on these social bearings. He notes that it requires of a human being to 'to carve out a reasonably ample livelihood for self, "family, and a potentially wide group of kin dependents, besides making substantial contributions to the well-being of society at large"' (Wiredu 1992: 200). What catches my attention in this regard is the suggested order of prioritisation of securing and distributing of an ample livelihood. It must start with oneself, family, kin and the society at large. On my part, I think Wiredu imposes this order to suggest partiality, i.e. our duties must start with ourselves, extended families and if possible be extended to the society at large. And, these duties lose the strength of intensity the further away they move from an agent (Metz 2012a). This interpretation of Wiredu is sustained by what he says in the same passage: 'The implied counsel, though, is not one of unrelieved self-denial, for the Akans are well aware that charity further afield must start at home' (1992: 200).

It is crucial to note that Wiredu appears to draw a distinction between one's 'special relationships' (self and family) and 'other people' to whom he refers to as 'potentially wide group'. Wiredu is very clear that one who becomes a good human being (person) is as a result of some personal exertion to improve her life. In this sense, a journey to moral perfection is a personal project, a partialist consideration, within the incubator of social context (Menkiti 2004: 326). It is important to note Wiredu also appears to be suggesting one owes immediate duty to self-development than to his family and, if possible, one can benefit a wider group. Then the assertion that 'charity further afield must start at home' rubber-stamps the partialist reading of other-centred partiality, i.e. as much as one has a duty to the community at large, that duty must be interpreted within the 
prism of partiality, which prioritises one's personal projects, family, friends and so far as is possible the community at large. ${ }^{9}$

So, we realise that the communitarian facet of promoting the common good is posited as a means for securing personhood. But, this communitarian facet should also be construed to reflect the indexical reasons that characterise African moral thought, where charity begins at home. In other words, one is expected, in her distribution of other-regarding duties, to prioritise her special relationships. Or, put differently, in the promotion of the good of all we must realise that we have greater and even more pressing duties to those close to us than to strangers.

My aim in this article was expository insofar as I sought to argue that the idea of personhood can be associated with two sorts of partialisms: the agent- and other-centred partialisms. But for the sake of demonstrating the robustness of partialism in an African moral context, I consider one objection against agent-centred partiality in African moral thought. This objection explores the feasibility of agent-centred partiality in an ethical paradigm that tends to emphasise the community over the individual (Menkiti 1984: 171). This tendency is also usually captured in the literature in terms of radical communitarianism, which puts the interests of the community over those of individuals (Gyekye 1992; Menkiti 1984). This objection is captured more succinctly in terms of what is called the 'potential dark side' of Ubuntu (Louw 2001: 19-26). This dark side of Ubuntu is captured in these terms:

In short, although it articulates such important values as respect, human dignity and compassion, the Ubuntu desire for consensus also has a potential dark side in terms of which it demands an oppressive conformity and loyalty to the group. Failure to conform will be met by harsh punitive measures. (Louw 2001: 19-26)

So, the fundamental concern here is that this fascination or even fixation with the centrality of community might undermine the agent-centred partiality since the individual will be forever under the galling yoke of the oppressive expectation for conformity and loyalty to the group. If truly Ubuntu does have this dark side of group-conforming-consensus that might limit the space for an individual to realise herself then it follows that this would render agent-relative partiality defeasible.

It is crucial to note that this objection about the relationship between the community and the individual is too big to be settled in this article. That said, I have some thoughts I think can give us some reasons to seriously think that the agent-centred partiality is central to African ethics. We must bear in mind that here we are not evaluating practitioners of African ethics but are concerned with the moral theory itself. I bring this fact to our attention because it appears to me that what Dirk Louw (2001) refers to as the potential dark side of Ubuntu may reasonably be construed to capture, not so much the ideals of Ubuntu as a moral theory, but how its practitioners might miss its true essence of prescribing a genuine or a true community. It strikes me as anti-Ubuntu to include things like 'totalitarian and oppressive' practices that constrict rather than allows individuals to morally flourish as its potential dark side (Shutte 2001: 14). So, to talk of the 'dark side' in question is not so much at a level of theorisation but of speculating about a possible abuse or misuse of Ubuntu as a moral theory by its practitioners, and every theory, I submit, is susceptible to such kind of abuse.

At a moral-theoretical level, scholars of African moral thought consistently observe that the securing or promotion of the common good is not opposed or does not thwart the achievement of the individual good. In fact, I remind the reader that Lutz notes: 
In a true community, the individual does not pursue the common good instead of his or her own good, but rather pursues his or her own good through pursuing the common good. The ethics of a true community does not ask persons to sacrifice their own good in order to promote the good of others, but instead invites them to recognize that they can attain their own true good only by promoting the good of others. $(2009: 314)^{10}$

It is crucial to note that Ubuntu as a moral theory operates on a basis of what it prescribes as a true community. In other words, Ubuntu seeks to give us a theory of a good society (Wiredu 2008:334). This true community is characterised by the ideals necessary for a true human life. A true human life is possible only in the promotion of the common good. But in the quest to promote the common good, the good of each individual is also secured. But this talk of the common good and the individual good should not be hastily construed to imply agent-neutrality. That would be to lose sight of the spirit of Ubuntu. Considerations of agent-relativity are suggested by Lutz above in the quote, when he observes that Ubuntu invites agents 'to recognize that they can attain their own true good only by promoting the good of others' (2009:314). Here, Lutz suggests that part of the reasons for promoting the common good are agent-relative because one knows and is motivated to promote the common good because that is the only means to also secure their own good. One is interested in the common good because it also entails their own good. This is consistent with the observation in the analysis above by Anthony Appiah (1998) that African ethics is informed by a rationale that is 'anti-universalizing' in that it is grounded on 'indexicality', which captures the reasons for acting in terms of agent-relativity. So, part of the reasons for promoting the common good it is the fact that it is also good for me.

Some scholars of African moral thought think it is an advantage or an attractive feature that the idea of personhood is characterised by agent-relative reasons. They say so because they believe it gives an explanation for why an agent should be interested in morality in the first place. Van Niekerk (2007) and Lutz (2009) submit that the advantage of a talk of attainment of personhood as informed by agent-relative reasons is good because morality is about the agent and her own perfection. It is precisely because perfection is good for her that she should care about morality. So, the agent is motivated to be moral because it is in her best interest. If Ubuntu is construed in a way that rules out this feature of agent-centeredness then it will have a tough time accounting for why an agent should care about morality at all.

\section{Conclusion}

In this article, I set myself a goal to philosophically analyse contributions of the moral notion of personhood to philosophy, particularly African ethics. I have argued that the idea of personhood has two facets, namely: the individualistic, and the communitarian. The individualistic facet points to the fact that the idea of personhood locates the ultimate good in perfecting something intrinsic to the individual. The communitarian facet points to the fact that one can only achieve personhood by relating positively with others. I concluded by showing how both the individualistic and communitarian facets are usually understood as essentially characterised by agent-relative reasons. In other words, I achieve personhood because it is good for me as an individual. And, when I promote the good of all, I have prior and weightier duties to my special relationships than I have to everyone else. 


\section{Notes}

1. To be fair, Thad Metz (2010) does attempt to offer justification for partiality by invoking the idea of relationships, but that is not the focus of the article. Elsewhere, I reject his relationship-based justification of partiality (Molefe, 2017b).

2. I invoke the three considerations to ground my argument: the high prize usually accorded to the family, the veneration of ancestors, and the normative idea of personhood.

3. Jason van Niekerk $(2007,2013)$ construes the idea of personhood in terms of what he calls the 'auto-centric' moral approach. Central to this idea is self-favouritism in the project of selfdevelopment. His focus however is not on teasing out the idea of partiality but to elaborate on the perfectionist interpretation of African ethics. My focus is on this idea of partiality as entailed in this notion of personhood.

4. Elsewhere, I have argued that Menkiti is best construed as analysing a normative conception of personhood (Molefe 2016c).

5. Ibid.

6. I take 'Ubuntu' to represent a sub-Saharan understanding of African ethics. This idea of a person features in this talk of Ubuntu. Central to the idea of Ubuntu is the maxim: 'a person is a person through other persons'. The first instance of a person should be understood biologically, to refer to a human being, and the second instance captures the normative idea under consideration in this article. Ubuntu can therefore be understood as a self-realisation account that enjoins human beings to achieve personhood, which they can only achieve by relating with others in a particular way (Metz 2010). To say someone has Ubuntu is to report that they have attained personhood.

7. See also Shutte (2001: 23) and Gyekye (2010).

8. This idea of partiality is usually justified by three competing considerations, namely: relationships, projects, and individual facts Michael Stocker (1976), Bernard Williams (1981), Susan Wolf (1992) and Diane Jeske (1997).

9. One may here object that there is a tension between the pursuit of the common good and the idea of partiality. It is not quite within this article to solve this puzzle but suffice it to say that it seems a reasonable and efficient strategy to approach the promotion of the good of all by focusing on those people she knows best and she is close to. Just on these considerations of logistics and efficiency it seems reasonable to see partiality as a reasonable strategy for promoting the good of all. Another useful way one may respond to this objection is by employing the distinction employed by Ramose (2003: 386), wherein he talks about the boundaries that characterise those in the inner and outer circles of partiality to be 'permeable'. In other words, partiality does not exhaust the scope of our duties, it merely imposes a hierarchy of our duties.

10. See also Wiredu (2008: 334) and Gyekye (2010).

\section{Disclosure statement}

No potential conflict of interest was reported by the author.

\section{Note on contributor}

Motsamai Molefe lectures Philosophy at the University of the Witwatersrand. His research focus is African Philosophy, Moral and Political Philosophy.

\section{References}

Appiah, A. 1998. 'Ethical systems, African', in E. Craig (ed), Routledge Encyclopaedia of Philosophy. <http://0-www.rep.routledge.com.ujlink.uj.ac.za:80/article/Z008SECT5> (accessed 4 July 2009).

Behrens, K. 2011. African Philosophy, Thought and Practice and Their Contribution to Environmental Ethics. Johannesburg: University of Johannesburg. 
Behrens, K. 2013. 'Two "normative" conceptions of personhood'. Quest 25:103-18.

Bell, D.A. \& Metz, T. 2011. 'Confucianism and Ubuntu: Reflections on a dialogue between Chinese and African traditions'. Journal of Chinese Philosophy 38:78-95.

Bujo, B. 1998. The Ethical Dimension of Community. Nairobi: Paulines Publications Africa.

Bujo, B. 2001. Foundations of an African Ethic: Beyond the Universal Claims of Western Morality. New York: The Crossroad Publishing Company.

Cottingham, J. 1983 'Ethics and impartiality'. Philosophical Studies 43(1):83-99.

Cottingham, J. 1986. 'Partiality, favouritism and morality'. Philosophical Quarterly 36:357-73.

Cottingham, J. 1991. 'The ethics of self-concern'. Ethics 101:798-817.

Donnelly, J. 1982. 'Human Rights as Natural Rights'. Human Rights Quarterly 4:391-405.

Godwin, W. 1973. An Enquiry Concerning Political Justice and Its Influence on General Virtue and Happiness. New York: Alfred A Knolf.

Gyekye, K. 1992. 'Person and community in African thought', in K. Gyekye and K. Wiredu, Person and Community: Ghanaian Philosophical Studies, 1. Washington DC: Council for Research in Values and Philosophy.

Gyekye, K. 1997. Tradition and Modernity. New York: Oxford University Press.

Gyekye, K. 2004. Beyond Cultures: Perceiving a Common Humanity, Ghanaian Philosophical Studies. Accra: The Ghana Academy of Arts and Sciences.

Gyekye, K. 2010. 'African ethics', in Edward N. Zalta (ed), The Stanford Encyclopedia of Philosophy. $<$ http://plato.stanford.edu/archives/fall2011/entries/african-ethics> (accessed 16 January 2013).

Ikuenobe, P. \& Kalumba, K.M. 2006. 'The idea of personhood in Chinua Achebe's things fall apart'. Philosophia Africana 9:117-31.

Jeske, D. 1997. 'Friendship, virtue, and impartiality'. Philosophy and Phenomenological Research 57:51-72.

Jollimore, T. 2014. 'Impartiality', in Edward N. Zalta (ed), The Stanford Encyclopedia of Philosophy $<$ http://plato.stanford.edu/archives/sum2011/entries/impartiality/> (accessed 27 May 2014).

Kaphagawani, D. 2004. 'African conceptions of a person: A critical survey', in K. Wiredu (ed), Companion to African Philosophy. Oxford: Blackwell Publishing.

Louw, D. 2001. 'Ubuntu and the challenges of multiculturalism in post-apartheid South Africa'. Quest (grand Rapids, Mich ) 15:15-36.

Louw, D. 2004. Ubuntu and the Challenges of Multiculturalism in Post-Apartheid South Africa. Utrecht: Centre for Southern Africa.

Lutz, D. 2009. 'African ubuntu philosophy and global management'. Journal of Business Ethics 84:31328.

MacNaughton, D. \& Rawling, P. 2006 'Deontology', in D. Copp (ed), Oxford Handbook of Ethical Theory. Oxford: Oxford Press.

Magesa, L. 1997. African Religion: The Moral Traditions of Abundant Life. New York: Orbis Books.

Masolo, D.A. 2010. Self and Community in a Changing World. Indianapolis: Indiana University Press.

Mbiti, J. 1969. African Religion and Philosophy. London: Heinemann.

Menkiti, I. 1984. 'Person and community in African traditional thought', in R.A. Wright (ed), African Philosophy: An Introduction. Lanham: University Press of America.

Menkiti, I. 2004. 'On the normative conception of a person', in K. Wiredu (ed), Companion to African Philosophy. Oxford: Blackwell Publishing.

Metz, T. 2007. 'Ubuntu as a moral theory: Reply to four critics.' South African Journal of Philosophy 26:369-87.

Metz, T. 2010. 'Human dignity, capital punishment and an African moral theory: Toward a new philosophy of human rights'. Journal of Human Rights 9:81-99.

Metz, T. 2012a. 'Ethics in Africa and in Aristotle: Some Points of Contrast'. Phronimon 13:99-117.

Metz, T. 2012b. 'An African theory of moral status: A relational alternative to individualism and holism'. Ethical Theory and Moral Practice 15:387-402.

Mokgoro, Y. 1998. 'Ubuntu and the law in South Africa'. Potchefstroom Electronic Law Journal 1:1-11. Molefe, M. 2016a. 'African ethics and partiality'. Phronimon 17:104-22.

Molefe, M. 2016b. 'A critique of Kwasi Wiredu's humanism and impartiality'. Acta Academica 48:89108. 
Molefe, M. 2016c. 'Revisiting the debate between Gyekye-Menkiti: Who is a radical communitarian'. Theoria 63:37-54.

Molefe, M. 2017a. 'Critical comments on Afro-communitarianism: Community versus the individual'. Filosofia Theoretica 6(1):1-22.

Molefe, M. 2017b. 'Relational ethics and partiality: A critique of Thad Metz's Towards an African Moral Theory'. Theoria 64:43-61.

Musschenga, A. 2005. 'The debate on impartiality: An introduction'. Ethical Theory and Moral Practice 8:1-10.

Nkondo, G. 2007. 'Ubuntu as a public policy in South Africa: A conceptual framework'. International Journal of African Renaissance Studies 2:88-100.

Rachels, J. \& Rachels, S. 2015. The Elements of Moral Philosophy. New York: MacGraw Hill.

Ramose, M. 1999. African Philosophy Through Ubuntu. Harare: Mond Books.

Ramose, M. 2003. 'The ethics of Ubuntu', in P. Coetzee and A. Roux (eds), The African Philosophy Reader. New York: Routledge.

Shutte, A. 2001. Ubuntu: An Ethic for a New South Africa. Pietermaritzburg: Cluster Publications.

Singer, P. 1979. Practical Ethics. Cambridge: Cambridge University Press.

Stocker, M. 1976. 'The schizophrenia of modern ethical theories'. Journal of Philosophy 73:453-66.

Tshivhase, M. 2013. 'Personhood: Social approval or a unique identity?' Quest: An African Journal of Philosophy 25:119-40.

Tutu, D. 1999. No Future without Forgiveness. New York: Random House.

Van Niekerk, J. 2007. 'In defence of an autocentric account of Ubuntu'. South African Journal of Philosophy 26:364-68.

Van Niekerk, J. 2013. Ubuntu and Moral Theory. Johannesburg: University of Witwatersrand.

Williams, B. 1974. 'Persons, character, and morality', in A.O. Rorty (ed), Identities of Person. Berkeley: University of California Press.

Williams, B. 1981. Persons, Character, and Morality. Cambridge: Cambridge University Press.

Wiredu, K. 1992. 'Moral foundations of an African culture', in K. Wiredu and K. Gyekye (eds), Person and Community: Ghanaian Philosophical Studies, 1. Washington, DC: The Council for Research in Values and Philosophy.

Wiredu, K. 2008. 'Social philosophy in postcolonial Africa: Some preliminaries concerning communalism and communitarianism'. South African Journal of Philosophy 27:332-9.

Wiredu, K. 2009. 'An oral philosophy of personhood: Comments on philosophy and orality'. Research in African Literatures 40:8-18.

Wolf, S. 1992. 'Morality and impartiality'. Philosophical Perspectives 6:243-59.

Wolf, S. 1999. 'Morality and the view from here'. The Journal of Ethics 3:203-23. 